\title{
Põhjapõdraohverdus ja nafta: põlisrahvaste õiguse ja rituaali dialoog
}

\section{Art Leete}

\section{(2) OpenEdition}

1 Journals

Édition électronique

URL : https://journals.openedition.org/efo/4760

DOI : $10.4000 /$ efo. 4760

ISSN : 2275-1947

Traduction(s) :

Sacrifices de rennes et pétrole : dialogue entre rituel et droits des peuples autochtones - URL : https:// journals.openedition.org/efo/4117 [fr]

Éditeur

INALCO

Édition imprimée

Date de publication : 1 janvier 2014

ISBN : 978-2-343-05394-3

ISSN : 0071-2051

\section{Référence électronique}

Art Leete, «Põhjapõdraohverdus ja nafta: põlisrahvaste õiguse ja rituaali dialoog », Études finnoougriennes [En ligne], 46 | 2014, mis en ligne le 25 novembre 2015, consulté le 06 octobre 2022. URL : http://journals.openedition.org/efo/4760 ; DOI : https://doi.org/10.4000/efo.4760

Ce document a été généré automatiquement le 6 octobre 2022.

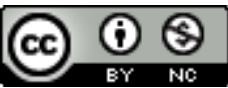

Creative Commons - Attribution - Pas d'Utilisation Commerciale 4.0 International - CC BY-NC 4.0 https://creativecommons.org/licenses/by-nc/4.0/ 


\title{
Põhjapõdraohverdus ja nafta: põlisrahvaste õiguse ja rituaali dialoog
}

\author{
Art Leete
}

\section{NOTE DE L'AUTEUR}

Uuringut toetas Euroopa Liit Euroopa Regionaalarengu Fondi kaudu (Kultuuriteooria Tippkeskus).

\section{Kokkuvõte}

1 Artiklis analüüsin 1996. aasta aprillis Lääne-Siberis Num-to järve ääres toimunud hantide ja metsaneenetsite kollektiivset põhjapõdraohverdust tiheda kirjelduse meetodil. Viibisin ise kirjeldataval ohverdustseremoonial, aga oma vaatlusandmetele lisaks kasutan põliselanike seletusi rituaali sisulise terviklikkuse ning selle elementide semantilise tausta avamisel. Üldisema konteksti kirjeldamise eesmärgil arutlen ka vaadeldava ohverduse seoste üle naftatööstuse surve vastu võitlemisel. Kokkuvõttes demonstreerin selle artikli kaudu, kuidas põlisrahvaste õiguste eest võitlemisel rakendatav hantide ja metsaneenetsite maailmapilt ja rituaalne praktika võimaldab seda võitlust integreerida traditsioonilise maailmapildiga sulanduvaks tegevuseks.

\section{Sissejuhatus}

2 Lääne-Siberi põlisrahvasteks on Uurali keelkonda kuuluvad obiugrilased (handid, mansid) ning samojeedid (tundra- ja metsaneenetsid). Sama piirkond on viimased pool sajandit olnud ka Venemaa tähtsaim nafta- ja gaasitööstuse regioon. Põliselanike peamised tegevusalad (jaht, kalapüük ja põhjapõdrakasvatus) on seotud 
looduskeskkonnaga ning nafta ja gaasi tootmine muudab võimalused traditsioonilise eluviisi järgimiseks üha ahtamaks. Seda nii keskkonnale avaldatava tööstusliku surve kui ka rahvastiku arvu ja struktuuri dramaatilise muutumise tõttu (alates 1960test on piirkonna elanike arv kasvanud 15 korda, samas on põliselanike arv jäänud suhteliselt stabiilseks). Need arengud toovad üldiselt kaasa põlise eluviisi taandumise, ent kohati põhjustavad hoopis selle eluviisi uuel moel väärtustamist ning traditsioonilise maailmapildi ja rituaalsete praktikate jõulisemat aktualiseerumist.

3 Nõukogude-järgsel ajal on Lääne-Siberi põliselanikud korraldanud rohkem ning avalikumalt kollektiivseid põhjapõdraohverdusi ning muid aktsioone, kus traditsioonilised rituaalid on seotud poliitilisele eliidile ja laiemale avalikkusele suunatud nõudmiste ja sõnumitega. Nendes osaliselt muutunud funktsiooniga rituaalides peegelduvad iseloomulikult piirkonna laiemad sotsiaalsed ja majanduslikud arengud.

4 Lääne-Siberi põliselanike kollektiivseid ning kohati ka avalikkusele suunatud ning poliitiliste nõudmistega põimitud rituaale on analüüsinud mitmed autorid. Anzori Barkalaja uurimused $(1997$; 1999) keskenduvad Pimi jõe hantide kollektiivsetele põhjapõdraohverdustele, mis olid seotud piirkonna kaitsevaimude austamisega ning kohaliku kogukonna kokkukuuluvustunde tõstmisega. Mina olen analüüsinud ametnike lavastatud handi põhjapõdraohverdust, mis korraldati rahvusvahelisele delegatsioonile Tromjugani jõel (Leete 2004). Eriti lähedaselt on käesoleva uurimusega seotud Eva Toulouze'i ja Liivo Niglase uurimused, kus puudutatakse ka tundra- ja metsaneenetsi põhjapõdraohverduste problemaatikat (Niglas 1997; Niglas, Toulouze 2004; Toulouze, Niglas 2012). Hantide erinevat laadi kollektiivseid põhjapõdraohverdusi on võrdlevalt analüüsinud näiteks Kustaa Frederik Karjalainen (1918), Andrew Wiget ja Olga Balalajeva (2011), aga ka Marjorie Mandelstam Balzer (1999). Natalja Novikova on korduvalt kirjutanud „presidendi põhjapõdra“ problemaatikast (1998; 199a; 2000; 2002), mis on otseselt seotud käesolevas artiklis analüüsitava kollektiivse ohverdustseremooniaga.

5 Põhiliselt on senised analüüsid olnud keskendatud kas üksikute rituaalide käsitlemisele, ohverduste üksikelementide sedastamisele või laiematele põhjapõdraga seotud küsimuste (nii majanduslike, rituaalsete, kui ka poliitiliste) tõlgendamisele. Käesolevas töös püüan neid momente integreerida. Vaatlen, kuidas on rituaali elemente võimalik ükshaaval tõlgendada, kuidas need moodustavad traditsioonilise sakraalse terviku ning mil moel seostatakse traditsiooniline rituaal tänapäevase võitlusega poliitiliste administraatorite ja naftatööstuse vastu.

6 Käesolevas artiklis analüüsin Lääne-Siberi põliselanike tänapäevast olukorda ning rituaali potentsiaalset rolli laiema poliitilise olukorra kajastaja ja mõjutajana läbi sündmuste rea, mis seostub 19. aprillil 1996 toimunud kollektiivse põhjapõdraohverdusega Handi-Mansi autonoomses ringkonnas Jugra, Belojarski rajoonis Num-to järve ääres pühas kohas. Ohverdamisel oli suureks eesmärgiks naftakompaniide poolt kavandatud ning osalt ka alustatud naftapuurimise ärahoidmine Num-to lähedastel aladel. Samas jääb põliselanike ja naftatööstuse probleem käesolevas artiklis teisejärgulisemaks. Keskendun ohverdusrituaali võimalikult tihedale analüüsile ja teen osutusi naftaküsimustele vaid piiratud mahus. Naftatööstuse ja põliselanike rituaalsete suhete küsimuse täpsem arutelu väärib eraldi analüüsimist.

7 Käsitlen nimetatud ohverdamist, järgides tiheda kirjelduse (Vt. Geertz 2001 [1973]) printsiipe. Olen Num-to ohverdamist käsitlenud ka varem (Leete 1997; 1999; Leete, 
Niglas, Barkalaja 2001), ent nüüdne tõlgendus on oluliselt põhjalikum. Ohverdamise käigus salvestatud teleesinemiste teksti avaldan teades, et põliselanike eestkõneleja Juri Vella (Aivaseda) (1948-2013) oli huvitatud antud materjalide näitamisest mõnes Venemaa kesksetest telekanalitest. Seega sooviti põliselanike liidri poolt Lääne-Siberi põliselanike õiguste ja elukeskkonna säilitamise ja teisalt - naftatööstuse laienemisega seotud kultuuriliste ja ökoloogiliste probleemidele võimalikult avalikku kõlapinda. Ka on Juri Vella korduvalt kinnitanud, et tema jaoks on oluline igasugune avalik tähelepanu Lääne-Siberi põliselanike olukorrale.

Põliselanikest informantidele uurimuses „hääle andmist“ on antropoloogilises uurimistraditsioonis oluliseks peetud juba aastakümneid (vt nt Radin 2008 [1956]). Samas pole lihtne leida adekvaatset dialoogi määra informantide teksti ja uurija tõlgenduste põimimisel. Kui esitada pikad tsitaadid väheste kommentaaridega, võib konteksti selgitus jääda puudulikuks ning esitatu lugejale arusaamatuks. Kui aga teha informantide jutule vaid põgusaid viiteid, peab lugeja täielikumalt usaldama uurijat põliselanike arusaamade adekvaatse edasiandmise küsimuses. Mina valisin lahenduseks lähenemisviisi, mille tulemusena annan oma võtmeinformandile palju sõna, ent püüan tema selgitusi ka mõnevõrra kontekstualiseerida varasemas kirjanduses esitatu ja teistelt informantidelt kuuldu kaudu.

Käsitlen vaadeldavaid sündmusi kui ilmekat näidet põhja põliselanike tänapäevasest ellujäämisvõitlusest. Põhjarahvaste elukeskkonna, inimõiguste ja -väärikuse kehtestamine toimus vaadeldaval juhul rituaali kontekstis. Sellega rõhutasid põliselanikud oma kultuuri põlisust ning kestvust. Teisalt ilmutas metsaneenetsite vaimne ja poliitiline liider Juri Vella aga ka silmapaistvat poliitilist taipu, mis muutis konflikti naftafirmadega omapäraselt intrigeerivaks. Taoline autentse ohverdusrituaali ning tänapäevase poliitilise võitluse põimumine ongi käesoleva uurimuse teemaks.

Num-to ohverdustseremooniale sattusin juhuslikult ning võimatu oli ka ette näha, kuidas see sündmus saab alguspunktiks põnevale loole presidendi põhjapõdrast. Viibisin välitööde ajal Hantõ-Mansiiskis, läksin külla handi folkloristile Timofei Moldanovile ning teejoomise ajal küsis ta, et ega ma ei soovi järgmisel päeval Num-to'le ohverdusele sõita. Teadmata midagi eesseisvast, olin kohe nõus. Arvasin, et see on osa viisist, kuidas asjad Siberis juhtuvad - sa satud justkui kogemata kuhugi ja saad midagi teada. Viljaka üldise hoiakuna Siberi välitöödel tundus lihtsalt ootamine, lootuses, et mingil hetkel hakkavad soodsad asjad juhtuma ning seda pole vaja jõulise asjaajamisega tagant kiirustada.

11 Järgmisel päeval ronisime helikopterisse (mille ohverdamise üks korraldajaid Juri Vella oli naftafirmalt välja nõudnud lubaduse vastu, et ei korraldata naftatööstuse-vastast piketti $\left.{ }^{1}\right)$ ning sõitsime Num-to'sse. Enne kohalejõudmist lendasime Lääne-Siberi ristipõiki läbi, korjates metsalaagritest peale tseremooniale siirduvaid hante ja metsaneenetseid, teiste hulgas Juri Vella. Käesolev kirjeldus põhineb minu poolt pärast ohverdamist 19. aprilli õhtul 1996 Num-to külas tehtud kirjalikel märkmetel ning mõnede asjaosaliste kommentaaridel.

12 Põhjapõtrade ohverdamine toimus Num-to järve lõunakalda lähedal väikesel saarel asuvas pühas kohas, Num-to külast umbes 1,5 kilomeetrit idas. Järve kaldal, saarest umbes 100 meetri kaugusel kasvasid 7 püha seedrit. Saarel kasvavad kased. Ilm oli ohverdamise ajal külm ja tuuline, selge, umbes 15-20 külmakraadiga.

13 Num-to ohverdamise käigu seletamisel oli minu põhiinformandiks kohalik hant Stepan Randõmov (1941-2005). Toetun oma uurimuses palju Stepani tõlgendustele. See on 
tingitud asjaolust, et Stepani seletused ohverdusrituaali üldise tausta ning paljude üksikelementide kohta on süstemaatilised, harmooniliselt seotud põliselanike maailmapildiga ning veendunult esitatud. Temaga suheldes oli selge, et Stepan võtab rituaali tõsiselt ning püüab kõike ausalt selgitada. Rituaali jälgides taipasin, et tegu on erilise mehega. Põhiosa osalejatest suhtusid toimuvasse rahuliku asjalikkuse või isegi mõningase hooletusega. Stepan aga askeldas kogu aeg ning nagu mulle tundus, toimetas rituaali detailide kallal, mis teised tema arust vahele jätsid. õhtul läksin talle külla ning ilmnes, et olin õigesti arvanud - Stepan ei hinnanud eriti kõrgelt neenetsite pühendumist ning oli seetõttu vaikselt tegelenud tähelepanuta jäänud detailidega.

Samuti lummas mind tema üldine käitumistiil, mis minu kogemuse kohaselt oli lähedane prototüüpsele handi etiketile. Tema igapäevane tegevus (nii vähe, kui ma jõudsin seda jälgida) oli täis pikitud usundist määratud elemente. Näiteks, kui käisin tal Num-to's külas, nõudis ta seda, et saaks mulle kingituse teha, sest kaugelt saabunutele tuleb midagi anda. See oli tema jaoks emotsionaalne küsimus ning seotud maailma asjade üldise korrasolemisega.

\section{Püha koht ja naised}

15 Ohverdusrituaalil ei osalenud kõik kohalikud elanikud, kellel selleks põimõtteliselt võimalus oli. Rituaali ajal sõitsid nartadel üle järve ohverdamiskohast mööda mõned neenetsid, tseremooniale tähelepanu pööramata. Stepani sõnul ei tahtnud need inimesed ohverdamisel osaleda:

"Kedagi eraldi ei kutsuta. Kes soovivad, need ise peavad sellistesse kohtadesse tulema. Need kaks sõitsid oma külasse, oma püstkotta mööda seda järve. Tavaliselt räägitakse ohverdamisest kõigile. Kõigile kuulutatakse, kes soovivad osa võtta. Noored ei taha osa võtta. Nende vanemad ei tegelenud selliste ohverdamistega ja ise nad ka ei taha."

Ohverdamisest osavõtjad, nii mehed kui naised, sõitsid mootorsaanide ja põhjapõdranartadega kohale üle jäätunud Num-to järve. Rakendijagu põhjapõtru kolm - seoti ohverduspaigas ühe kase külge. Ohverdusele olid saabunud ka naised (nii kohalikud kui ka põlisrahvaste aktivistid Hantõ-Mansiiskist), kes Stepani hinnangul olid sinna lubatud põhjusel, et ohverdati kõigile jumalatele korraga. Kui ohverdus oleks olnud pühendatud ainult "sellele kõige valgemale taevasele jumalale", oleks rituaalile lubatud ainult mehed. Stepan kommenteeris naiste ja meeste erinevaid rolle ja õigusi rituaalses kontekstis ka põhjalikumalt:

"Ja kui siis [ohverdamisel üle jäänud põhjapõdraliha] koju tuuakse, naisi [sellega] ei toideta. Ei külmutatuga, ei keedetuga. Ainult mehed [söövad]. Aga neenetsitel on mõned sellised perekonnad. Nad [ohverdavad] koos naistega taevastele jumalatele, päikesele, kuule, kõik koos. On sellised neenetsid, ma ise tean. Siis lubatakse. Valgele jumalale riputasid [kase otsa] valge [põhjapõdra]naha koos peaga. Koos naistega saabusid palvetama. See on lubatud. Tulid koju, naistel lubatakse samuti liha süüa. Ja meestelgi. Aga on ka sellised paigad, kuhu sõidavad ainult mehed. Need on kõrgemad kohad. Ronid kuhugi künkale, vaatad - oo! Metsast kõrgemal on seal püha koht näha. Aga tegelikult, kui sõidad põhjapõdrarakendiga, siis [mõnikord] on [püha koht] 40-50 kilomeetri kaugusel. Sellised kohad asuvad peamiselt jõgede ülemjooksudel, jõgede vahel. Siin lähedal, Kazõmi ääres ja mujal on ka sellised kohad. Need on sellised maad, kuhu naise jalg üldse ei astu."

17 Seega tunnistab Stepan, et naiste rituaalsed õigused võivad perekonniti varieeruda. Ka tõstab Stepan esile, et naiste võimalused rituaalses tsüklis osalemiseks on suuremad 
neenetsite seas. See võib olla viide neenetsite seas valitsevale suuremale üldisele sotsiaalsele vabadusele. Samas jäi mulle mulje, et Stepan peab siiski silmas seda, et neenetsid käituvad tema silmis valesti, lubades naistele liiga palju. Kogu Stepani seletust rituaalist läbib arusaam range tseremoniaalse korra järgmise vajadusest. Et talle endale oli ohverduse läbiviimise kord detailideni selge, võis ta igas olukorras näha teiste inimeste eksimusi. See polnud minu hinnangul pahatahtlik suhtumine neenetsitesse või naistesse, vaid siiras mure rituaali korrektse läbiviimise pärast. Stepani maailmapildi mehhanism tundus keskenduvat täpsele rituaalsele korrale, ilma milleta ohverdustseremoonia ei toimiks - jumalad ei saaks sõnumeid kätte ning valesti toimunud rituaali tõttu võivad ka inimesed kannatada.

18 1996. aasta Num-to ohverdusrituaali puhul põimusid soorollide küsimused eriti tähelepanuväärselt tseremoonia toimumispaiga erilise sakraalse tähendusega. Stepan juhtis mu tähelepanu ka Num-to järve ja selle keskel asuvate pühade saarte suhtele inimeste rituaalsed käitumisega ning vastavate normidega:

"Sellel järvel on maakitsus, nagu inimese või looma kael. [Sealt edasi] on pea. Ning selles peas endas on kaks püha kohta. Mitte ühegi naise jalg pole [sinna] astunud. Silmad, silmade moodi. Kaks kaskedega saart, kuus kaske [kasvab seal], kaks silma asuvad selles pühas järves. Järves, külast nelja kilomeetri kaugusel, on saar, mis loetakse südameks. Kui järve linnulennult, lennukist või helikopterist vaadata, on see nagu elus loom. Süda, pea, silmad, seal on ka patsid. Jõekesed lähevad nagu patsid."

Huvitav on Stepani tõlgendus Num-to järvast kui antropozoomorfsest pühast olendist. Stepan selgitas Num-to südamelaadse saare olulisust veel kord, rõhutades vaid meeste ligipäs̈su sellele paigale:

"[Üks saar] asub püha järve keskel. Seda saart peetakse seepärast pühaks, et ta on nagu järve süda. Sinna pole kunagi naise jalg astunud, sellele pühale kohale. Ainult mehed käivad seal. Seekord tõime ohvri järve kalda ääres, kuhu oli kõigil võimalik kogu perega sõita, koos lastega. Sinna võivad kõik koos naistega minna."

Enne ohverdamisele sõitu kahtlesid naised Num-To's, kas neid üldse kaasa võetakse. Oleks ohverdamine toimunud suurel pühal saarel, polekski naisi kaasa võetud. Arutuse all oli ka võimalus ohverdustseremoonia korraldamiseks Num-to tähtsaimaks saarel, ent sellest loobuti.

21 Väike saar polnud nii püha, samuti polnud see ainult meeste püha koht. Seepärast võeti ka naised kaasa. Ja ohverdamise rituaalne eesmärk oli nii üldine, et seegi soodustas naiste kaasavõttu. Samuti toetas seda ohverdamisele laiema kande- ja kõlapinna leidmise vajadus. Avatuma ligipääsuga pühapaika sai probleemideta lubada kõik külalised ja põlisrahvaste organisatsioonide esindajad, kelle seas oli ka naisi. Taolisel viisil esindas ohverdusel osalejaskond nii konkreetsemalt kui ka sümboolsemalt kogu rahvast. Samas polnud naistel alati juurdepääsu ka kaldaäärsesse ohverduspaika. Eelmisel ohverdamisel samas paigas oldi ilma naisteta, nagu ütles hant Sergei Griškin tele-raadiokompaniist "Jugoria". Muidu toimus aasta varem rituaal sarnaselt jumalatele ohverdati kolm põhjapõtra, rakenditäis.

22 Stepan seadis Num-to pühapaikade erilisuse ka laiemasse geograafilisse ning põliselanike eri gruppide varieeruvate ligipääsuvõimaluste konteksti:

"Igal sugukonnal oma kohta pole. Sellised kohad, nagu see Num-to järv, on väga vanad. Ja igal jõel on oma nimetus, oma jõenimetus on ka püha. Num-to järv on kõigile rahvastele ohverdamise jaoks. Aga igaüks enda juures, oma sugukonnamaadel selliseid kohti ei oma. Ja varem samuti polnud sellist asja. Ja praegu ei ole sellist asja. 
[Kui inimene saabub teisest piirkonnast ja tal on vaja põhjapõder ohverdada, siis] ta ostab põhjapõdra raha või viina eest. On selline tava, et igaüks peab siis inimesele müüma. Ta võib lennuki või rongiga kohale sõita. Ta ei saa endaga kuidagi [põhjapõtra] kaasa võtta. Aga kohapeal, asulast või külast või püstkojast peab ta kohalikelt ostma põhjapõdra. Ükskõik kellelt küsitakse, igaüks müüb põhjapõdra."

Stepani kirjeldus osutab sellele, et Num-to on põliselanike seas laialt tunnustatud püha piirkonnana. samas ilmneb ka, et teatud üldised rituaalsed reeglid on laiapõhjaliselt jagatud, üksteist toetatakse tseremoniaalsete põhivõimaluste tagamisel. Seegi on oluline vaadeldava rituaali laiapõhjalisuse taustana. Num-to piirkonna elanike seisukohalt polnud erakordne, et inimesed tulevad kaugelt sinna ohverdama. Erakordne oli sündmuse mitmekihilisus, eeskätt poliitilise mõõtme jõuline rakendamine ning püüd avalikkust laialdaselt teavitada.

Ohverduspaiga iseloomustamisel on oluline ka värvisümboolika järgimine ning rakendus põliselanike poolt. Rituaalne värvide mäng läbib rituaali kogu kulgemist ning saab alguse juba püha koha valikul ning kujundamisel. Kaskedele olid riputatud põhjapõdranahad koos peade ja sarvedega. Need olid pärit eelmistest ohverdamistest. Kaskedele oli riputatud ka riidetükke ja kangaribasid. Kask on valge puu, mis on põliselanike maailmapildi kohaselt seotud valgete jumalate ja Ülailmaga, kus need jumalad hantide ja neenetsite uskumuste kohaselt elavad. Stepan selgitas eelmiste ohverdusrituaalide tulemusena pühapaika jäetud põhjapõdranahkade ja kangaste küsimust ka seoses reegliga, et pühapaigast ohverdamise tulemusel tekkinud objekte kaasa ei võeta (erandiks on ohvriloomade liha, mida tuleb kõigil osalejatel kaasa võtta):

"Need nahad, mis praegu püha kase otsas ripuvad, pandi sinna siis, kui üle-eelmisel aastal sõitsime sellesse samasse kohta esimest korda. Kui seal ohverdad, siis nahk ja pea koos riidetükkidega seotakse sinna, jäetakse igaveseks. Neid põhjapõtrade nahku ja sarvedega päid endaga kaasa ei võeta."

Eelmiste ohverdusrituaalide esemeline pärand on muutunud pühapaiga iseloomulikuks ning paratamatuks osaks. Pühakohta lisatud valged objektid võivad suurendada paiga loomulikku pühadust (mille kehtestavad valged kasepuud). Üldine mulje Stepani selgitustest kinnitab arusaama teatud rituaalsete elementide kuhjamisese vajadusest. Nagu allpool täpsemalt esitatud, korratakse ohverduse käigus pidevalt erinevaid tegevusi ja ohverduspaika kogutakse-lisatakse objekte, et kindlustada teatud püha väe toimimist või sidemete tugevust jumalatega.

\section{Rituaali algus}

6 Tsemoonia esimesed tegevused olid kooskõlas tavalise ohverdusrituaali käiguga. Pühas kohas süüdati lõke, mille kohal hakati ämbritega vett keetma. Lõkke jaoks olid halud kodust kaasa toodud. Stepan selgitas, et tule olemasolu oli rituaali jaoks fundamentaalse tähtsusega:

"Tehti lõke üles. Sest et lõke, tuli, on kõigist sajast jumalast tugevam. Sellepärast, et lõkkes võib kõik ära põleda. Seepärast tehti alguses lõke üles. Lõke [põles] seni, kuni ohverdamisel istuti ja rahvas ja kõik. [Jälgiti] et lõke ei kustuks, et põleks."

Huvitav, ent mitte ühemõtteline, on Stepani väide tule "kõigist sajast jumalast tugevam" olemisest. Pole selge, kas tuld käsitletakse siinjuures võimsaima või ühe tugevama jumalana, omapärane substants, mis on jumalatest võimsam või hoopis kindlaim ühendusviis jumalatega, mida viimastel pole võimalik ignoreerida? Ja kes on 
sada jumalat? Kas taevased jumalad (mis oleks tegelikult veider) või on tuli alama järgu jumalatest tugevaim? See sisaldas nii regiooni kui ka Venemaa liidritele ning televaatajatele mõeldud kõnesid. Need pidid aitama teadvustada põlisrahvaste olukorda, ent ka näidata, kuidas kavatsetakse järgnevat rituaali ning igapäevast religioosset käitumist rakendada põlisrahvaste õiguste avalikul kaitsmisel.

Kõigepealt esinesid metsaneenets Juri Vella, hant Maria Kuzminitšna Vagatova-Voldina (Hantõ-Mansiiskis ilmuva handikeelse ajalehe "Hantõ Jasang" toimetaja, handi luuletaja, pärit Num-to kandist) ja Juri Vella naaber Oleg Aivaseda (samuti metsaneenets) teleraadiokompanii "Jugoria" võttegrupile. Räägiti Num-to ümber asuvate alade naftavabadena säilitamise vajadusest ja traditsioonilisest kultuurist. Samuti märgiti seda, et Juri Vella pühendab ühe emase valge põhjapõdra Venemaa presidendile (ohverdamise hetkel Boriss Jeltsinile, ent edaspidi päranduks see põhjapõder või tema järglased järgmistele presidentidele), Oleg Aivaseda aga HandiMansi autonoomse ringkonna kubernerile (ohverdamise hetkel Aleksander Filipenkole). Mõte oli selles, et president ja kuberner omavad nüüd Juri Vella ja Oleg Aivaseda karjades oma osa ning kohaliku keskkonna saastamine kahjustab nii presidendi kui kuberneri omandit. Järgnevalt esitangi kõnede teksti.

Juri Vella: "Me saabusime püha järve, Num-to äärde, mis asub nafta leiukohal. Selle paljusid jõgesid toitva järve kaldal, oma sugulaste juuresolekul, tahaksin ma kinkida ühe põhjapõdra. Ma andsin täna juba raha ära. Ma ostan oma sugulaselt põhjapõdra 
Venemaa presidendi jaoks. Kui Boriss Nikolajevitš Jeltsin soovib enne valimisi selle põhjapõdra ära viia, maha lüüa või teisele edasi anda, olen valmis seda igal ajal tegema. Kui Boriss Nikolajevitš Jeltsin enne valimisi seda põhjapõtra minu karjast ära ei vii, siis pärast valimisi saab selle põhjapõdra endale see kandidaat, kes võidab presidendivalimiste maratoni.

Vastavalt minu sugukonna uskumustele võib see põhjapõder elada igavesti. Tähendab, mil moel? Kui see põhjapõder vananeb, jääb haigeks ja ma tunnen, et ta tunneb end halvasti, tapan ma ta lihaks. Asemele panen oma karjast noore tugeva põhjapõdra.

Aga samas, vastavalt minu sugukonna tavadele, võib see põhjapõder kaduda päriselt. Ta võib hukkuda õnnetusjuhtumi tagajärjel või lähedasest naftaleiukohast tulnud salaküti relvast. Ainult sellisel juhul võib see presidendi põhjapõder kaduda. Ja on veel üks võimalus presidendi põhjapõdra hukkumiseks või kadumiseks - kui tema karjamaa hävitatakse kellegi või millegi poolt ja sellel põhjapõdral ei ole võimalik millestki toituda.

Ma annan sõna Venemaa praegusele ja tulevasele presidendile, et rakendan kõik jõud, et tema põhjapõder elaks võimalikult kaua. Ning tõotan, kõigi minul olemas olevate võimete ning jõududega, rakendada kõik pingutused, kõik jõud karjamaa kaitseks igasuguse tegevuse eest selle kahjustamisel. See on karjamaa, kus hakkab karjas olema presidendi põhjapõder, s.t. minu sugukonna karjamaa.

See ongi kõik, mis ma tahtsin jutustada selle püha järve, Num-to kaldal oma sugulaste juuresolekul teie jaoks, meie Handi-Mansi autonoomse ringkonna elanikud."

Oleg Aivaseda: "Mina olen Varjogani külanõukogu elanik ning saabusin siia, püha järve Num-to äärde selleks, et ohverdada sellele pühale kohale koos oma kaasmaalastega. Ning samuti tahan ma oma autonoomse ringkonna kubernerile, seltsimees Filipenkole kinkida ühe põhjapõdra, oma isikliku põhjapõdra. Selleks, et ta ikkagi pööraks meie rahvale tähelepanu, mingisugustki tähelepanu."

Juri Vella: "Nähtavasti tahad sa pöörduda ringkonna kuberneri poole, et ta aitaks kaitsta sinu karjamaad?"

Oleg Aivaseda: "Jah. Ma kingin selle jaoks, et ta aitaks mul kaitsta minu karjamaad, minu põhjapõtru ning sealhulgas hakkab ta kaitsma ka oma põhjapõtra. Ning selle põhjapõdra võib ta kohale saabudes igal ajal minu karjast ära viia, kui tal vaja on. Ning hoida kus talle sobib."

Juri Vella: "Ja milline see põhjapõder on?"

Oleg Aivaseda: "See põhjapõder on valget värvi."

Juri Vella: "Emane?"

Oleg Aivaseda: "Jah, emane, kes hakkab andma järglasi. Ning las hoolitseb järglaste eest seltsimees Filipenko ise."

Juri Vella: "Muide, ma unustasin öelda, et põhjapõder, mille ma kuulutasin Venemaa presidendile, see põhjapõder on samuti emane. Ning on täiesti võimalik, et juba mõne aasta pärast ei ole enam üks presidendi põhjapõder, vaid on juba mitu põhjapõtra.

Muide, veel üks väike detail. Naftamehed Kogalõmmist kohustusid minu perele tekitatud kahju hüvitamiseks eraldama naftatööstuse töötaja keskmise kuupalga. See on umbes 3 miljonit.

Aga üleeile toodi mulle neid rahasid 1 miljon $^{2}$. Ma arvestasin, et ostan selle raha eest presidendile terve rakenditäie põhjapõtru, see tähendab kolm põhjapõtra. Aga kahjuks jätkus mul raha ainult ühe põhjapõdra jaoks. Ja seetõttu pühendan ma Venemaa presidendile ainult ühe põhjapõdra."

Maria Vagatova-Voldina: "Ma tahan öelda, et ühest küljest sõitsin ma praegu siia sellise suure rõõmutundega. Sest siin oli lapsepõlv, siin olid põhjapõdrad. Palju, palju põhjapõtru.

Aga nüüd on inimesed ärevuses ja võtsid vastu pöördumise. Ma arvan, et see on õiglane nõudmine ja palve, et püha järv, Num-to, selle maad jäetaks rahule. Sellepärast, et selgub, et juba seisavad puurtornid. Aga meie olime oma ringkonnas, 
mõtlesime, et Num-to maa on seni puutumata. Selgub, et valu on siin sama hiiglaslik, nagu ka Surguti, Nižnevartovski, Neftejuganski rajoonides.

Ja aitäh, et inimesed täna sellises kohas täpselt niisamuti armastavad põhjapõtru, täpselt niisamuti nagu kõik inimesed. Ja kõige paremaid kinke jagasid nad kuberneri ja Venemaa presidendiga. Muidugi, kui meie näiteks kirikusse ei lähe, ei hakka seal midagi [paluma]. See on meie ainuke püha koht, mis on jäänud kogu tundrasse. Seetõttu ühinen ka mina kõigi nendega, kes kirjutasid alla, pöördudes kahe ringkonna kuberneride poole.

Ja kes täna pöörduvad taeva poole, kes tõid siia ka kõige hinnalisemad kingitused, terve rakendi. Annaks Jumal, et me kõik, kõik soovime, et meid ei jäetaks sellest ilma."

Juri Vella: "Tahame kinnitada meie jumalate ees justkui pitsatiga. See ohverdamine, mille me täna läbi viime, põhjapõtrade pühendamine jumalatele, see ongi see, et usaldame kinkeaktiga Venemaa presidendile ja ringkonna kubernerile põhjapõdrad. Ja usaldame oma pöördumise, mille saadame praegu ringkonna kubernerile sellest, et see maa on vaja ikkagi säilitada." rituaal edasi traditsioonilises vormis. Suur naiste osakaal ning telemeeste tegevus jätsid küll toimuvale mõningase jälje (naiste paiknemine ja liikumine tuli meestekesksesse rituaali sobitada ja kaamerasilma ees tegutsemine kammitses ehk pisut ohverdamise läbiviijaid, tehes nende liikumised jäigemaks ja oleku tõsisemaks). Ent rituaali elementide paljusus ning sümbolite selgus raamistasid tegevust piisavalt, nii et suurem osa rahvast oli pidevas tegevuses rituaali käigushoidmisega ning vahepealne mõningase formaalsuse esiletõus üldist askeldust oluliselt ei häirinud.

Kõnede lõppedes asetati seedrite ja ohverdajate vahele lumele riie ja sellele annetused. Igaüks pani, mida oli kaasa toonud: barankad, snickersid, kommid, paberossid "Priima", viinad, tee. Stepan tegi märkuse annetuste asetusviisi kohta, pidades riide olemasolu 
soovitavaks, ent aktsepteerides ka võimalust asetada annetused riide puudumisel otse lumele. See oli üks väheseid kohti, kus Stepan loobus küllaltki range rituaalse korra kontseptsioonist ning tunnistas erinevate lahenduste lubatavust:

"Nad panid pudelid otse lumele. Ma vaatasin. Aga mul oli riie endaga kodust kaasa võetud. Mul oli siin just ülejääk. Nägin, et ripub naela otsas, võtsin kaasa. Pärast panin selle punase riide lume peale. Siis pandi pudelid selle peale. Nad panid lume peale, puhtale lumele. Neil polnud midagi kaasas. Siis muidugi tohib. Paned pudeli ja topka viinaga otse lume peale. Aga mina tean, kuidas meie tavad on. Võtsin metsa punase riide kaasa. Oli vähem kui meeter pikk."

Viinapudeleid oli seitse, s.t. kolm liitrist viina ja üks "poolik" (tavapäraselt peetakse prototüübiks pooleliitrist viinapudelit, seega loeti liitrised kahe viina eest). Seda täheldas Stepan kinnitas ka hiljem intervjuu käigus:

"Ohverdasime seitsmele jumalale-vaimule. Meil oli seitse pudelit. Täpselt seitse. Suured pudelid ju, seal on [justkui] kuus [väikest pudelit]. Ja seitsmes veel väike pudel. Nii tuligi meil välja täpselt seitse pudelit."

39 Et viinapudeleid oli seitse, peeti oluliseks. Siinjuures võib kergesti mõista analoogiaseost traditsiooniliste kosmoloogiliste arusaamadega. Seitse on obiugrilaste ja neenetsite maailmapildis olulisim arv - sama palju usutakse taevas elavat tähtsamaid valgeid jumalaid, ka ülailma kihte on seitse (Rombandejeva 1993). Ohverdusele saabunud ei püüdnud spetsiaalselt, et viinapudelite arv seostuks jumalate ja pühade maailmasfääride arvuga. Eelnevalt polnud ohverdajad omavahel kokku leppinud, kuipalju viina kaasa võetakse. Kohapeal lihtsalt vaadati, et on võimalik tekkinud olukorda tõlgendada viisil, et toodud on seitse viina, täpselt niipalju kui vaja. Ühelt poolt kajastab see seik asjaolu, et juhuslik kokkusattumus on hea, see näitab, et toimuvat on pälvinud jumalate vaikiv soosing (vt Novikova 1999a). Teisalt peegeldab see juhtum ka põliselanike paindlikku rituaalset strateegiat - kui kokkulangevus kosmoloogilise harmooniaga pole esmapilgul ilmne, võib otsida sobivat tõlgendust, tuvastada sobiv annetus ja jumalate heasoovlik soosing mõnevõrra hägusamast või ambivalentsemast sõnumist.

\section{Kõige paiknemine ohverdamise ajal}

Lisaks piirkonna üldisele pühadusele ja seosele põliselanike maailmapildi totaalse topograafiaga, oli oluline ka inimeste ning loomade asetus rituaali ajal. See sakraalne mikrotopograafia kandis rituaali toimimise seisukohalt käivitavat või üldise harmoonia tagamise funktsiooni.

Ohverdatavad põhjapõdrad seoti puu küljest lahti ning pandi ritta, peadega lõunasse, päikese, Ülailma, valgete jumalate, aga ka kaasatoodud annetuste ning seedrite poole. Mehed seisid kaares põhjapõtrade taga ja naised omakorda meeste taga, koondudes läänekaare poole [lõuna-põhjasuunalisest mõttelisest rituaalsest teljest (seedrid annetused - põhjapõdrad - mehed - Num-to järv) jäid naised kõrvale]. Stepan pidas seda paigutuse küsimust piisavalt oluliseks ning komplitseerituks, mis vajas detailsemat, ent ka avaramat lahtiseletamist:

"Aga valgetele jumalatele, taevastele, [palvetatakse] alati päikese poole. Kui mustale jumalale, Hõn-iki'le, siis koidu poole. Siis peab põhjapõder selles suunas olema asetatud. Noored ei teadnud. Nad asetasid meie vastu [peaga põhja poole]. Aga see hall, valgepea, Num-to kõige vanem vanamees, Täkvjak, talle tuli korraga meelde. Tema ütles, et põhjapõdrad pange peadega päikese poole. Noored panid alguses 
põhjapõdrad meie vastu. Meie vastu, öö poole. Et päris surnud oleksid. Meie ju kõigepealt palusime elu, palvetasime. Kui vanamees poleks öelnud noortele, oleksin ise öelnud, et pead peavad olema päikese poole. Noored panid kõigepealt öö suunas. Kui öö poole, mustale jumalale, siis võib asulas ohvri tuua. Siis poleks me pidanud ilmtingimata sinna [pühapaika] sõitma. Me oleksime võinud need ohvrid tuua siinsamas asulas. Arvatakse ju, et need jumalad, mustad ja taevased, on omavahel tülis. Must jumal [tegutseb], kui nad palju viina võtavad, jäävad purju. Juhtub, et üks tapab teise, üks läheb vangi."

üldse. Kas mustadele jumalatele võib siiski ohverdada, ent loomad sel juhul "surevad päriselt" - st taevastele jumalatele annetades nad ei sure, vaid sünnivad ümber? Stepan pidas vajalikuks pöörduda selle küsimuse juurde tagasi ning selgitada mustadele jumalatele ohverdamise asjaolusid lähemalt:

"Seedrid on mustale jumalale, Hõn-iki'le, kellele ohverdatakse samuti. Seitsme seedri juures varem vanamehed, meie vanaisad, kes seal kaldal samuti [ohverdasid]. Sellel kohalt, kus meie ohverdasime, 50 meetri kaugusel järve kaldal jäi üks suur vana seeder alles. Ja kasvas veel kuus noort. Ja seisavadki seitse seedrit. Sinna tuuakse ka ohvreid, see on mustale jumalale. Samuti sellele pühale järvele. Must jumal, temaga on seotud must puu, seeder. Seedrile riputatakse samuti riidetükke. Mustale jumalale tuuakse ainult musta värvi põhjapõder. Aga valgele, taevajumalale täiesti valge põhjapõder. Mustale jumalale [ohverdamisel] on põhjuseks see, et inimestel haigusi ei oleks, et inimesed ei sureks. Palvetatakse niisamuti nagu sellele taevasele järvele. Niisamuti tuuakse ohvrid. Samuti põhjapõdrad, viin, toiduained. Laud pannakse ka."

Nagu ilmneb, pole valgetele ja mustadele jumalatele ohverdamisel rituaali elementides paljus vahet (kui värvisümboolika ning paiga- ja suunavaliku erinevus kõrvale jätta see erinevus toimib sümmeetria põhimõttel, rituaali baasmomendid on ümberpööratud, imiteerides sellega maailma üldise ülesehituse põhijooni). Stepan lausa rõhutab, et palvetamine toimub sarnaselt, nagu ka toidu- ja joogiannetuste asetamine. 

palvetamise ajaks pead paljaks. Suurem osa jättis aga pead kaetuks. Kõigepealt luges Täkvjak pika palve. Siis luges lühema palve veel ka Oleg Aivaseda. Stepan selgitas hiljem palve sisu ja ka konteksti, mis määras palvele just sellise iseloomu:

"[Täna ohverdati] sellele pühale järvele. Num-to, Taevane järv, sellepärast on püha järv. [Palusime,] et elu kohalikel, põliselanikel, kõigil [hea oleks]. Et lapsed kõik rahulikult elaksid ja siin üleskasvanud inimesed kõik nendes paikades, kus isademad kõndisid, elaksid. Et ei unustaks [neid kohti].

Aga kes tahavad, et nende lapsed unustaks, see on juba nende asi. Sellised ei kuula, ei usu ka jumalat. Siis ei sunni ka lapsi jõuga. Kes tahavad, kuulavad vanemaid. Siia sõitsid ju noored kohale. Ema ja isa ju 100 aastat ei ela. Nemad jäävad pärijateks. Et nemadki käiksid seal ohverdamas. Ühes ja samas kohas. Kus vanaisad käisid. Kus me ka täna käisime. See ohverdamine oli pereelu jaoks, et lapsed elusad-terved oleksid. Et põhjapõdraõnn oleks. Neenetsid elavad ju kõik põhjapõtradega.

See vana Täkvjak, hall vanamees metsaneenetsite seast on kõige vanem, kes alles on jäänud oma põlvkonnast. Seepärast usaldati [palvetamine] temale, et ta [paluks] kõiki püha järve taevasi jumalaid, vaime, et nad kõik põhjapõdrad hästi oma kätte võtaksid. Peale põhjapõtrade oli seal veel ande. Kõik kohalesõitnud - kes tõi viina, kes toiduaineid. Nad tegid kõik laua peale valmis. Seitse pudelit viina pandi sinna ja seitse topkat viina pandi. Et need püha järve taevased jumalad, vaimud kõik selle koos põhjapõtradega hästi, külalislahkelt vastu võtaksid. Jutustas kõiki jumalaid, kui palju on taevasi jumalaid olemas on, kõiki. Sada jumalat, kui palju on, kõiki, igat jumalat eraldi kutsus siia. Kaltaš-imi ${ }^{3}$... Neid on palju, ei saa kokku lugeda."

Palved olid üldise iseloomuga: paluti head elu kõigile, põhjapõdrarikkust, lastele rahu ja võimalust elada seal, kus nende esivanemad elavad, aga ka seda, et lapsed jumalaid ei unustaks. Palvete üldise iseloomu tingis rituaali sakraalse eesmärgi mõningane ebamäärasus. Kohal oli palju inimesi ja paluma pidi midagi, mis puudutaks kõiki. Seda on aga kõige lihtsam ja kindlam teha, paludes head elu üldiselt. Teisalt oli rituaalil poliitiline, naftatööstuse ja sellega seotud poliitiliste arengute vastane kallak. Püüd siduda põlisrahvaste õiguste kaitse üritus ohverdusrituaaliga kõigi valgete jumalate jaoks võis tekitada samuti osalistes segadust oma poliitilis-religioosse 
uuenduslikkusega. Jumalatelt võis siis paluda põhjapõdraõnne, mis ehk pidi andma muuseas ka vihje, et naftatööstuse vohades seda õnne olla ei saa.

Stepan tõi mõni päev pärast rituaali esile, et palved õnnestusid täielikult ning seda näitas asjaolu, et tseremooniale järgnenud päeval oli ilus ilm:

"Kui me ohverdama läksime, oli halb ilm, nüüd on ilm selge. Me palusime, et kui tagasi lendad, et oleks ka hea ilm. Ohverdasime, et ära lennates oleks hea ilm. Siis veel ka selleks, et siiasõitnutel elus oleks teeõnn. Tuisk, torm, on selline ilm. Meil on tavaliselt selline tava. Et kui perekonnale või üksikule inimesele lendab õnnetus, siis nende jaoks [palume õnne].

Aga kui kõigi jaoks [palume], siis, et siiasõitnul oleks hea selge ilm selleks, et siit ära lennata helikopteri või lennukiga. See on selleks hea, et kõik vaimud ja jumalad, kellele me palvetasime, rõõmustaksid."

Ilm on teelolles oluline eksistentsiaalne küsimus, ent Stepani tõlgenduses ka pikemas perspektiivis või metafoorsemas mõttes tähtis (et "elus oleks teeõnn"). Stepani arusaamise järgi näitasid jumalad ilusa ilma kaudu, et nad suhtusid läbiviidud rituaali ja palvetesse heatahtlikult.

\section{Põhjapõtrade ohverdamine}

Pärast palvetamist põhjapõdrad tapeti. Kaks neenetsit hoidsid lassot põhjapõdra kaela ümber ja tõmbasid eri suundades. Kolmas neenets lõi põhjapõdrale kirvesilmaga kuklasse. Enne imiteeris ta igat lööki kaks korda ja lõi alles kolmandal korral. Esimene põhjapõder kukkus alguses vasakule küljele. Neenetsid pöörasid ta kiiresti paremale küljele. Stepani selline asjade käik mõnevõrra häiris ning ta täheldas, et ohvriloom peab alati kukkuma paremale küljele. Aga kui seda ei juhtu, siis ei jää muidugi üle muud, kui loom ümber pöörata.

Paremale küljele kukkumisega saadakse jumalatelt sõnum, et ohvriloom on vastu võetud. Samas on võimalik selles küsimuses ka tulemust mõjutada, keerates valesti kukkunud looma õigetpidi. Et taoline tegevus näib olevat aktsepteeritud, siis pole see kukkumine ilmselt ühemõtteliselt teade jumalate meeleolu kohta ja inimestepoolne põhjapõdrapööramine on sõnum headest kavatsustest. Võib olla ka nii, et tegu on justkui läbirääkimistega. Jumalad lükkasid küll esimese hooga ohvri tagasi, ent inimesed pakkusid seda uuesti ja siis jäid jumalad rahule (põhjapõder jäi ju lõpuks ikkagi paremale küljele lebama).

Ülejäänud kahte põhjapõtra tõugati pärast kirvega löömist juba spetsiaalselt nii, et nad kohe paremale küljele kukuksid. Mahakukkunud põhjapõtradele torgati noaga veel südamesse ja kuklasse. Siis veeti tapetud põhjapõtru lume peal ringi päripäeva. Tapetud kolm põhjapõtra asetati seejärel ühte viirgu maha, peaga lõuna suunas. Stepan oli neenetsite sellise tegutsemisega rahul, see sobitus tema arusaamaga korrektse rituaali läbiviimisest:

"[Põhjapõtru pööratakse lumel] üks kord päripäeva. Valge, hall vanaisa Täkvjak ütles noortele, et nad pööraksid [tapetud põhjapõtru] veel ühe ringi päripäeva. Nagu päike tiirleb. On tava, et niimoodi inimene pöörab sellistel pühadel ohverdamistel. Palvetas kõigile jumalatele, vaimudele, ja pärast seda peab ta päripäeva kolm korda ringi tegema."

Tapetud põhjapõdrad asetati lumele põhjapõdrarakendina. Valge põhjapõder, vasakpoolne, oli juhtloom. Jalad jäeti põhjapõtradel ida poole. Valge põhjapõdra pead keerati 90 kraadi (koonuga taeva poole), sarved torgati lumme. Siis lõi Stepan 
Randõmov põhjapõtradele lassoga vastu külgi ning tegi liikuma-ärgitavaid häälitsusi. Valge põhjapõder tõmbles selle peale, mis tähendas, et valged jumalad on ta vastu võtnud. Viimane põhjapõder värises lassolöögi peale ka natuke, aga seda Randõmov ei arvestanud. Õigupoolest Randõmov ei näinud viimase põhjapõdra liigutamist, sest keeras enne ohvrilooma tõmblusi põhjapõdrale selja. Stepan selgitas oma tegevust kui vajalikku põhjapõtrade lõplikuks surmamiseks ja valgete jumalate juurde saatmisel:

"Ülemiste jumalate juurde [saatmiseks] hoitakse põhjapõtru peaga päikese poole. Öö poole ei tohi [hoida]. Me asetasime nad rakendina. See sarvedega oli juht. Juhi võtsid nad hästi vastu. Isegi pärast, kui ma lassoga lõin kolm korda, liigutas ta hukkununa kolm korda. Aga need kaks äärmist, kukkusid ja olid juba surnud. Too juht võeti kohe vastu, kui me vaimudele palvetasime. Kõik, keda puudutati [lassoga], need põhjapõdrad peavad südamega kolm korda liigutama, et nad kohe surnutena ei kukuks. Kindlasti on vaja neid lassoga kolm korda lüüa, et nad liigutaks. Pärast lebab põhjapõder juba surnuna, aga [alles] siis, kui oled teda lassoga kolm korda löönud."

Tõmblused näitavad ohvri aktsepteerimist jumalate poolt. See näitas, et juhtlooma kukkumine valele küljele polnud lõplikult halb märk ja jumalad võtsid ohvri siiski omaks, sest ülejäänud tegevused sooritati korrektselt.

"Kohe surnuks kukkumine" ja "päris surnud olemine" on väljendid, mida Stepan kasutab juhul, kui ohverdamise juures midagi valesti läheb. See osutab ilmselt põliselanike arusaamale, et õige rituaali käigus sureb ohvriloom järk-järgult. Seetõttu on vaja kõik ohverdamise etapid korralikult läbi viia, et loomaga teel valgete jumalate juurde midagi ei juhtuks selles mitte päris surnud olekus, milles ohvriloom esialgu asub või kus teda tuleb mõnda aega hoida. Välistatud pole, oluliste rituaalsete eksimuste puhul võib ohver sattuda valgete asemel mustade jumalate juurde. Seegi on järeldus, mida Stepani juttu järgides on võimalik teha.

Pärast põhjapõtrade tapmist ja nende seadmist lumele ühte viirgu seisid mehed jälle põhjapõtrade taha, näoga lõuna poole, naised ja külalised lääne poole põhjapõtru, näoga itta. Siis karjusid kõik kõva häälega seitse korda ja pöördusid päripäeva ümber enda, tehes igasse ilmakaarde kummardusi. See toimus küll segiläbi, nii et tegelikult ei teinud kõik ühepalju pöördeid ega kummardusi. Stepani seletuse kohaselt pidanuks siiski kõik neid tegevusi läbi viima seitse korda:

"Jumalad, vaimud kutsuti kõik kohale, et need kuuleksid. Võib-olla mõni ei kuulnud. Teda ei kutsutud. Pärast seda karjuvad seitse korda. Ja seitse ringi [tuleb teha] samuti pärast seitset karjet. Kõigist jumalatest, kes maa peal olemas on, kõige tähtsamad valged taevajumalad on need. Nagu isa ja ema ja päike, seitse poega, seitse tütart. Seepärast seitse korda. Aga teistel ohverdamistel niimoodi seitset korda ei karjuta. Ainult kolm korda. Kui nad kõiki ei kutsu. Aga praegu kõiki jumalaid, kes on olemas maa peal ja taevas, kõik kutsuti. [Ja ohverdati neile] terve põhjapõdrarakend."

1 Nagu Stepani tõlgendusest ilmneb, märkis seitsmekordne hüüdmine ja pöördumine ohverduse pühendamist kõigile tähtsamatele jumalatele. Kui võtta arvesse, et Stepani väitel olid kõik maapealsed jumalad oodatud, siis pole ime, et võis arvestada võimalusega, et väheste hüüete ja kummarduste järel võis osa jumalaid ikka veel kutse tähelepanuta jätta.

Põliselanike maailmapildile on omane mõningane jumalate laiskus, ignorantsus ja püüd end lõbustada inimeste arvel nalja visates. Näiteks tunnevad Kazõmi handid jumalat Rat ole 
„nagu käskjalg, kui ohverdamisel mõne jumala poole pöördutakse. Kui jumalat pole kohal, ta on kuhugi mujale kutsutud või on ta seotud oma asjaajamistega, läheb Rat ole䜿 iki mõne teise jumala juurde ja kui ka see on hõivatud, siis kolmanda juurde, kuni leiab jumala, kellel on aega inimeste palve täita" (Semjon Juhlõmov, 55 a, VM 1992).

63

64

\begin{abstract}
Taolises kontekstis on arusaadav, et põliselanikud püüdsid võimalikult jõuliselt ja ühemõtteliselt jumalatele oma kavatsused ja soovid selgeks teha (et jõuda ka ignorantsete jumalateni ning vältida palve mõttest möödahiilimist jumalate poolt). Seega oli tegemist mitte robustse röökimise, vaid jumalate iseloomu arvestades adekvaatselt valitud kommunikatsioonistrateegia rakendamisega.
\end{abstract}

\title{
Lassode viskamine okstesse
}

Pärast palvetamist katsid ohverdamise juhid oma pead kapuutside või mütsidega. Lassod , mis ohverdatud põhjapõtradel kaelas olid, visati kaskede okstesse. Kaks jäid okstesse rippuma, kolmas kukkus maha. Stepan pidas seda lassoviskamist järjekordseks möödapääsmatuks rituaali osaks:

"Need lassod, millega põhjapõdrad olid kinni seotud, visatakse [kaseokstesse]. Et nendelt kolmelt põhjapõdralt kõik vaimud, jumalad [tähelepanu pööraksid] sinna, [kus] kellelgi veel oma põhjapõdrad on. [Et oleks] põhjapõdraõnn, et põhjapõdrad kasvaksid suureks, elaksid hästi. [Et oleks] õnn, edu kalapüügil, jahil. Et kui keegi läks kuhugi jahile, loomi püüdma, et iga loomake talle ise vastu tuleks. Nüüd puid ei olnud, nad viskasid lihtsalt sinna [võssa]. Lasso visatakse kindlasti puu otsa. Ükskõik millise puu otsa. Kui ainult lähedal puu oleks."

Stepani seletuse kohaselt on tapetud põhjapõdrad selleks hetkeks juba jumalatega koos ning lassode kaudu liigub jumalate vägi loodetavasti ka inimeste ja loomade maailma ning soodustab mitmeid olulisi protsesse (põhjapõtrade paljunemine ja tervena püsimine, kalanduse ja jahi edukus). Mainimist leiab ka uskumus, et vaimud saadavad jahimehele loomi. Taia tõhususe tagab lasso okstesse rippuma jäämine. Mahalangenud lassod on halb märk.

\section{Ohvritoidu söömine}

Seejärel hakati kaasatoodud ohvritoitu sööma. Neenetsid alustasid söömisega ning Täkvjak jagas topkaga viina. Iga kohalolija sai ühe topkatäie. Viinaklaas anti edasi päripäeva. Pudel oli Täkvjaki käes. Tema valas viina klaasi ning andis mõnele ohverdamises osalejale, kes selle tühjaks jõi ning Täkvjakile tagasi andis. Täkvjak valas taas viina ning ulatas klaasi järgmisele kohalolijale, kes istus, põlvitas või kükitas eelmisest vasakul. Alustasid mehed, pärast tulid einestama ja viina võtma ka naised. Stepan seostas eine rituaalse tegevusena seekaudu, et just oli kutsutud kõiki vaime ja jumalaid ning seega pidid nad juba kõik kohal olema:

"Praegu kutsuti kõik vaimud, jumalad. Ja [neile kaeti] laud koos põhjapõtrade ohverdamisega. Kõigepealt seisid topkad. Seitse topkat, seitse pudelit. Et poleks 
paarisarv topkasid, neli või kuus või kaks. Topkades oli viin. Esimene topka tuleb anda lõkkele, tulejumalale. Kõik peavad jooma. Praegu esmajärjekorras antakse meestele üks topka. Aga kui kõik mehed on topkad võtnud, mis sel ajal laual seisid, kui jumalaid, vaime kutsuti, siis pärast tuleb naiste järjekord."

Einestamise alguses viis Stepan varem väljavalatud ja tapmise ajal jumalate jaoks seisnud topkatäie viina lõkkesse, kuna tuli on Stepani sõnul "kõige tugevam saja jumala seas". Samal ajal luges ta palveid, tehes seda vene keeles. Soovid olid väga üldised - et kõigil hästi läheks, et kõik terved oleksid ja kõik ilusti koju tagasi jõuaksid (paljud ohverdamisel osalejad olid tulnud kaugelt, mitte ainult Num-to'st ja ümberkaudsest tundrast). Vene keeles palvetas Stepan seepärast, et kõik aru saaksid (televisioon filmis teda samal ajal). Pealegi saavad jumalad aru igast keelest, nagu Stepan hiljem seletas. Pärast palvet kummardus Randõmov eri ilmakaarte poole, pöördudes samal ajal päripäeva enese ümber kolm ringi. Stepan ohverdas tulele paljapäi.

Stepani palve sisu oli järgmine:

"Kõige tugevamale jumalale, tulele... teie lapsed, kõik... inimesed terved oleksid, et

külalised, kes siia sõitsid, tagasi hea ilmaga sõidaksid, terved oleksid."

Palve sõnumi üldisus oli oluline sarnastel põhjustel, mida olen lahanud juba eespool - et tagada palutu täitmine, hoida suur osalejate hulk sakraalses ohutuses ja vältida liiga tagasihoidlikult esitatud palve puhul jumalate trikke (sõna-sõnalist palutu täitmist, mis ei pruugi inimesi tegelikult rahuldada, nagu eespool osutatud).

\section{Põhjapõtrade tükeldamine}

71 Kui mehed said söönuks, hakkasid nad põhjapõtru nülgima ja tükeldama. Nahad koos peadega (ilma alalõualuudeta) asetati natuke kõrvale - aga siiski ninadega enam-vähem lõunasse.

72 Enne ohvriloomade nülgimist võeti juhtloomalt heledad riidetükid kaela ümbert ära ning seoti kaseokstesse. Hiljem, enne nahkade ja peade lumele asetamist, seoti need riidetükid juhtpõhjapõdra äralõigatud pea külge tagasi.

73 Stepan Randõmov võttis kruusiga põhjapõtrade lahtilõigatud kõhust verd ning loopis mitmes suunas ohverdamiskohast eemale, põhisuunaga lõunasse, seedrite poole, sektor moodustus aga umbes kagust edelasse. Stepan viskas verd seitse korda. Ise seletas Stepan oma tegevust taas kõigi olulisemate jumalate meeleheaga ja tava range järgimise vajadusega, sarnaselt eelmiste seitsmele jumalale pühendatud tegevustega:

"Võtsin [verd] kolmest põhjapõdrast, [viskasin] seitsmesse kohta. Üle seitsme jällegi ei lubata. Kui viinatopkad võtsime, siis oli jälle niisamuti [seitse tükki]. Vaimudele, jumalatele, see kõik on nende jaoks. Me palvetasime vaimudele. Üle seitsme [korra verd visata] ei lubata. Seepärast [ohverdati] seitsmele jumalale-vaimule, et meil oli seitse pudelit. [Võtsin] verd kolmelt põhjapõdralt. Vaatasin, et keegi ei taha [seda teha]. Noored ilmselt isegi ei tea. Ma [hoian] oma tavasid, nagu vanemad mind õpetasid. Ja ma tegin selle kõik ise ära."

Lahtilõigatud lihatükid jäeti lumele vedelema, osa viidi ämbritega lõkkele keema. Samal ajal söödi ja joodi edasi. Aega kulus selles rituaali osas kõige rohkem, vähemalt paar tundi. 


\section{Vahepealsed etteasted}

75 Kuigi suurem osa mehi oli loomade tükeldamise ja keetmisega hõivatud, oli see faas rituaalis kõige vähem intensiivne. Pigem hakkas domineerima sündmuse meelelahutuslik külg. Saabusid handid, Aleksei Moldanov koos oma poegade Timofei ja Grigoriga. Nad tulid nartadega 54 kilomeetri kauguselt Kazõmi jõelt. Neil oli ka pudel viina kaasas. Aleksei suhtles kõigiga aktiivselt, esines televisioonile ja laulis pikalt.

Pingelisem hetk (mis küll suuremale osale kohalviibijatele märkamata jäi) kujunes siis, kui Täkvjak laulma hakkas. Ta palus televisioonil oma esinemine spetsiaalselt üles võtta, pidades seda laulmist väga oluliseks. Täkvjaki kõrval seisis paljapäi Stepan Randõmov ja vaatas neenetsile kogu aeg tähelepanelikult otsa, kummardades aeg-ajalt lõuna suunas. Stepan selgitas selle situatsiooni olulisust nii kohalikele neenetsitele laiemalt kui ka isiklikumas mõõtmes:
"Vanamees hakkas laulma, et noored tema laule pärast tema surma samamoodi laulaksid. Siis jutustas põhjapõtradest. Kuidas me põhjapõdrad ohverdasime. Kuidas laua panime. Selle lauluga [pöördus ta] jälle kõigi jumalate poole, kutsus kõiki kohale.
Senikaua kuni ta laulis, vaatasin ma kogu aeg talle silmadesse. Ma olen rahvuselt hant. Mul on naine neenets. [Kartsin], et äkki ta nõiub mingid needused mulle peale. Tahtsin [seepärast] kuulata. Tal üks silm - vasak - ei näe. Aga paremast jooksid juba pisarad. Ta laulis laulu. Seepärast ma vaatasin tema nägu, et ta laulis laulu, aga hinges tundis, et tal pole enam palju elada jäänud selle järve kaldal."

Seega arvas Stepan, et Täkvjak soovis televisiooni abil oma laulu säilitada tulevastele neenetsite põlvkondadele. Samas oli see laul ka sõnum jumalatele, et veelkord kindlustada ohverduse õnnestumine. Huvitaval moel oli Täkvjaki laulul ka nõiduslik potentsiaal, mida Stepan püüdis ära tabada või isegi ära hoida selle realiseerumist. See nõiduse võimalus võis tuleneda Täkvjaki vanusest, mis asetas ta erinevate maailmate piirialale. Samas asetusid kõik rituaalis osalejad teatud mõttes tõenäolisemasse kontakti jumalate ja vaimude maailmatega. Et valgete jumalatega seotud ohverdusrituaali käigus võis kergesti sattuda ka mustade jumalate, halbade vaimude ja sellega seotud ohtude mõjusse, on ilmne ka Stepani kommentaaridest põhjapõtrade asetuse ja mustade jumalate probleemile.

\section{Pudelite jätmine pühapaika, ohvriliha söömine ja noorte neenetsite õpetamine}

Tühjaks joodud pudelid torkasid neenetsid Stepan Randõmovi eestvõttel puuokste otsa. Stepan seletas seda esmalt vajadusega prügi vedelemajätmist vältida. Samas esitas Stepan sellelegi tegevusele rituaalse selgituse:

"Kui seal juba püha järv on. Selliste taevaste jumalate, vaimude jaoks jõid metsas selle pudeli tühjaks. Jõid viina ära. See viin on ju ka [and] nendele jumalatele. Nad on ju elusad, nad leiavad viina igalt poolt. Jätad selle tühja pudeli, nad panevad teinekord jälle täis. Ma teen alati nii.

Praegu me olime siin, istusime. [Noored neenetsid küsisid:] "Mis sa kaseoksi murrad ja pudeleid [oksa otsa torkad], kas ilu pärast või?" Mina rääkisin, et hoian oma tavasid. Teie jõite ju tühjaks, aga jumalad leiavad ka viina. Võib-olla said nad kuskilt kanistritäie viina. Selle peab ju kuhugi välja valama. Ma teen alati nii. Ainult kaseokste otsa [torgatakse pudeleid]. Teistele puudele pole lubatud." 
Stepani seletuse kohaselt on jumalad altid sarnastele lõbustustele nagu inimesedki. Seejuures on jumalate viinahimu või joomisvõime inimeste omast ilmselt suurem. Või on neil üleloomulik võime leida palju viina korraga.

Valge viina pudelite torkamine kaseokste otsa kätkeb endas veel ühe seose kinnitamist Ülailmaga rituaali käigus. Viina käsitlemine heade jumalate joogina näitab ka seda, et iseenesest alkohol vaimses mõttes halb ei ole. See võib aga olla üks ambivalentsetest elementidest põliselanike maailmapildis. Viina tõttu võib inimene kergemini sattuda Allilma vaimude mõju alla, ent see on ka oluline Ülailma jumalatega suhtlemisel.

81 Ka ilmneb siinkohal eksplitsiitselt didaktiline moment noorte harimisel. Stepan sekkus avalikult rituaali käiku harva ning tavaliselt neenetseid nende rituaali läbiviimisel ei õpetanud. Stepan rõhutas korduvalt, et on ohverdamisel külaline, kuna on hant. Pigem viis ta üksi läbi rituaalseid tegevusi, mida pidas oluliseks, aga mida neenetsid ei teinud. Samas oli noorte rituaalse käitumise jätkusuutlikkus Stepanil ikka hingel. Ta oleks hea meelega näinud, et noored neenetsid omandaksid ning kasutaksid sihiteadlikumalt vajalikke rituaalseid oskusi ja teadmisi.

82 Stepan kurtis, et keegi noortest ei teadnud, kuidas taig käib. Kõike tehti tema sõnul valesti. Söödi juba keedetud liha, aga toorest liha polnud keegi veel söönud. Stepani sõnul pidanuks inimesed kõigepealt sööma toorest liha ja alles seejärel seda keetma hakkama. Stepan seletas neenetsitele, millises järjekorras tegelikult peab asju tegema ning et süüa tuleb vähemalt tükike toorest liha. Noored neenetsid kuulasidki teda ning kogusid rahva toorest liha sööma (kogu liha polnud keema pandud). Osa inimesi sõi seejärel ka toorest liha. Alul polnud soola, siis see toodi. Toorelt söödi erilise mõnuga põhjapõdramaksa, mis olevat "neenetsi snickers". Samal ajal toimus ka üleüldine keeduliha söömine.

\section{Põhjapõdrapeade ja -nahkade riputamine kase otsa}

83 Kui seegi eine läbi, võeti kolm nahkadega põhjapõdrapead ja viidi kasepuu juurde, millise Täkvjak oli vahepeal välja valinud. Õiget puud otsides kõndis Täkvjak hõredas puudetukas natuke siia-sinna ja osutas siis ühele pisut suuremat sorti puule. See oli üks vähestest puudest, millistele selles ohverduskohas üldse oli mõeldav neid nahku ja päid riputada.

Puu juurde läksid mehed rivis üksteise järel. Üks neenets ronis puu otsa. Talle visati lasso ots. Ülevalolija tõmbas lasso üle oksa ja viskas otsa teisele poole alla. Nahad ja pead tõmmati üksteise järel lasso abil üles puu otsa. Puu otsas olnud neenets kinnitas need puu külge, sättides sarved okste vahele. Nahad jäid kase külge rippuma, pead ülespoole.

85 Esimese, valge põhjapõdra ülestõmbamise ajal karjuti üheskoos seitse korda. Mehed seisid ümber puu, näoga puu poole. Pärast kõigi kolme põhjapõdra puu otsa tõmbamist algatasid naised tagumises reas taas karjumist. Naised huilgasidki paar korda ja jäid vait. Mehed ei reageerinud. Naised seisid tagapool, näod läände, aga see oli juhuslikult nii. Nad ei orienteerinud endid mingit pidi. Stepan selgitas toimunut taas läbi sakraalsete maailmate seoste aktualiseerimise:

"Kase otsa [riputati põhjapõtrade nahad ja pead] seepärast, et kask on taevane puu, loetakse seotuks valge taevajumalaga. Kaske ei raiu me kunagi küttepuudeks. Kase otsa riputataksegi. Valgetele jumalatele tood ohvriks kolme meetri pikkuse valge 
riide või valge põhjapõdra. Riputad ta üles tervenisti - nahaga, peaga, sarvedega. Ainult kase otsa [riputatakse]. Püha puu. Seal ju riputati nahad samamoodi. Ainult kask [kõlbab]. Aga teised, mänd või kuusk, selleks ei sobi. Ja ka teised rahvad igal pool elavad niimoodi. Teistes regioonides."

Seose kinnitamine ja pöördumine valgete jumalate poole toimus seega kogu rituaali vältel, selle kõigil etappidel. Stepan pööras sellele pidevale suhtlemisele taevaste jumalatega suurt tähelepanu. Tema jaoks oli kogu ohverdustaig sellest läbi imbunud, see oli keskne, ühendav tegevus kõigi rituaali üksiktegevuste vahel.

\section{Rituaali lõpp}

Pärast ohvriloomade peade ja nahkade puu otsa riputamist koristati kõik pühasse kohta kaasatoodu - liha, ülejäänud lõkkepuud, põhjapõtrade tapmise järel kaseokstesse heidetud lassod - taas buraanidele ja nartadele ning kõik ohverdamises osalenud sõitsid kogu kraamiga tagasi Num-To külla.

Enne lahkumist tuli kõigil nartaga kohapeal päripäeva väike ring teha. Üldse kõik pöörded nartadega nii saabudes kui lahkudes tuli teha päripäeva. Üks noor neenets tegi teadmatusest pöörde vastupäeva, mis ei jäänud Stepani poolt märkamata. Viimaseks lahkujaks jäi Täkvjak, ohverdamise juht, kes ootas, kuni teised ära sõitsid. Seni ta laulis. Juri Vella oli pea lõpuni koos temaga. Istusid narta peal ja naeratasid, kui nad parajasti ei laulnud.

Sellega oli ohverdamine läbi. Õhtul pärast ohverdamist käisid inimesed Num-To's veel üksteisel külas. Joodi teed ning lauldi palju.

\section{Diskussioon: rituaali autentsus ja poliitika}

91 Num-to'l 1996. aasta aprillis toimunud kollektiivse ohverdamisrituaali esitatud tõlgendus põhineb Stepan Randõmovi seletustel. Tema tegevus ohverduse ajal andis mulle sõnumi, et tegu on inimesega, kes teab rituaalist palju ning tema hilisemad selgitused kinnitasid seda arvamust piisavalt. Stepan suutis rituaali detaile analüüsida ning haarata ka tervikut ning laia usundilist konteksti.

Rituaali traditsiooniline olemus seisis mõnevõrra lahus selle poliitilisest ambitsioonist. Stepani jaoks ei paistnud põlisrahvaste õiguste eest võitlejate püüdlustel olevat mingit tähtsust. Samas oli poliitiline sõnum ohverdusel selgelt olemas ning selle edastajatele oli rituaali korrektsus põhimõtteliselt oluline. Ohverduse sakraalsed ja poliitilised juhid olid erinevad ning üksteise tegevusse ei sekkutud. Rituaali läbiviijad lasid kõik võõrad ohverdusele ja lasid ohverduse tegevuste vahel pidada kõnesid. Poliitilise poole esindajad lasid ohverdamise läbiviijatel teha kõike nagu nad õigemaks pidasid. Samas eeldati, et autentsuse nõuete vastu siiski ei eksita ning sel teemal esitati isegi kriitilisi kommentaare (kahtlustades, et kohalikud ei suhtunud rituaali korralikku läbiviimisesse piisava tõsidusega).

93 Eksplitsiitselt ilmnes rituaali poliitiline külg tseremoonia algusjärgus peetud kõnedes, kus peasündmuseks oli Venemaa presidendile ja Handi-Mansi autonoomse ringkonna kubernerile põhjapõdrade kinkimine. Samuti avaldati meelt naftafirmade tegevuse laiendamise vastu Num-to lähistele. President ning piirkonna kuberner haarati 
metsaneenetsite tavade kohaselt koos põliselanikega Lääne-Siberi keskkonna saastamise ohvrite hulka.

Oluline on seegi, et enne ohverdustseremooniat kirjutati Num-to's alla põhjapõdrakasvatajate deklaratsioonile, mis esitati Handi-Mansi autonoomse ringkonna kubernerile. Deklaratsioonis nõuti Num-To äärsete maade säilitamise vajadust ning rõhutati, et neid pühasid maid ei tohiks anda naftakompaniidele.

Num-to avalik ohverdamine erineb poliitilise aktsioonina regioonis tehtud teistest katsetest ühendada traditsioonilise kultuuri elemendid põliselanike õiguste eest võitlemisega. Seni oli põlisrahvaste õiguste eest võitlemisel korraldatud pikette, mille omapärasemaks elemendiks oli püstkoja püstitamine (naftatööstust teenindavale trassile 1990. aastal ja Hantõ-Mansiiskisse autonoomse ringkonna administratsiooni hoone ette 1995. aastal) (Novikova 1999b; 2000). Ohverduse ja ühiskondliku protesti ühendamine oli innovaatiline samm, millel puudusid eeskujud ja ettevõtmine tervikuna sisaldas palju improvisatsioonilist elementi. See oli püüd seostada põliselanike maailmapilt ja rituaalne praktika kaasaegse poliitilise keele koodidega senitundmatus ulatuses. Polnud lihtne saavutada tasakaal, et rituaali autentsus oleks järgitud ja poliitiline sõnum piisavalt jõuline, mõistetav ka põliselanike kultuurist kaugetele ametnikele ja poliitikutele.

Rituaalne sõnum oli kõige jõulisemalt väljendatud selles, et Juri Vella pühendas põhjapõdra Venemaa presidendile, mis on leidnud laialdast kajastamist ajakirjanduses ja teaduslikes uurimustes (Novikova 1998; 1999a; 2002; Utrom 2003; Hanzerova 2009; Niglas, Toulouze 2004; Toulouze, Niglas 2012). Juri Vella on seda presidendi põhjapõdra küsimust hiljem pidevalt avalikult tutvustanud ning kasutanud argumendina hilisemates konfliktides LUKOILiga (järgides loogikat, et naftatööliste omavoli ohustab Venemaa presidendi omandit ning põhjapõdra ja presidendi vahelise sakraalse sideme tõttu ka presidenti). Just põhjapõdra pühendamine muudab Num-to ohverdamise poliitilise momendi ajas kestvaks. Kirjeldatud rituaal ei jäänud eksootiliseks episoodiks põlisrahvaste õigustele tähelepanu tõmbamisel, vaid toimis alguspunktina põliselanike maailmapildiga põimitud poliitilisele diskursusele ja põhjendusena hilisematele naftatööstuse vastastele aktsioonidele. Seda protsessi võib mõista viisil, et kui rituaal oli autentne, siis on fundamentaalselt õigustatud ka naftavastane poliitiline praktika.

\section{BIBLIOGRAPHIE}

VM = autori välitööde materjalid.

BALZER Marjorie Mandelstam, 1999, The Tenacity of Ethnicity. A Siberian Saga in Global Perspective, Princeton University Press.

BARKalajA Anzori, 1997, “On the Sacrificial Ritual of the Pim River Khanty in December 1995”, Pro Ethnologia 5, Tartu, p. 57-68.

Barkalaja Anzori, 1999, "On the Sacrificial Rituals of the Pim River Khanties: Part Two", Pro

Ethnologia 8, Tartu, p. 57-72. 
GEERTZ Clifford, 2001 [1973], The Interpretation of Cultures: Selected Essays, New York: Basic Books.

HANZEROVA 2009 = ХАНЗЕРОВА, ИРИНА, « ИСТОРИЯ ПРЕЗИДЕНТСКИХ ОЛЕНЕЙ »,НАРЬЯНА ВЫНДЕР 01.08.2009.

KARJALAINEN Kustaa Frederik, 1918, Jugralaisten uskonto. Suomen suvun uskonnot III, Porvoo : Werner Söderström OY.

KULEMZIN 1980 = КУЛЕМЗИН В. М. « О ЧУВСТВЕ СТРАХА У ХАНТОВ-ОХОТНИКОВ », іПВОПРОСЫ ЭТНОКУЛЬТУРНОЙ ИСТОРИИ СИБИРИ, ТОМСК : ИЗДАТЕЛЬСТВО ТОМСКОГО УНИВЕРСИТЕТА, p. 107112.

КULEMZIN 1984 = КУЛЕМЗИН В. М., ЧЕЛОВЕК И ПРИРОДА В ВЕРОВАНИЯХ ХАНТОВ, ТОМСК : ИЗДАТЕЛЬСТВО ТОМСКОГО УНИВЕРСИТЕТА

LEETE Art, 1997, “Sacrificial Ceremony at Lake Num-To”, Pro Ethnologia 5, p. 35-55.

LEETE Art, 1999, "Ethnopolitical Comments About the Sacrificial Ceremony at the Lake NumTo", Pro Ethnologia 7, p. 21-26.

LEETE Art, Liivo NIGLAS, Anzori BARKALAJA, 2001, Põhjapõder arktilises kultuuris,Tartu : Eesti Rahva Muuseum.

LEETE Art, 2004, "Ritual, Politics and Mentality: The Nenets and Ob-Ugrians of Siberia", in AnnaLeena SIIKALA, Stein MATHISEN (eds.), Creating Diversities: Folklore, Religion and the Politics of Heritage, Studia Fennica Folkloristica 14, Helsinki: Finnish Literature Society, p. 125-135.

MOLDANOV, MOLDANOVA 2000 = МОЛДАНОВ, ТИМОФЕЙ, МОЛДАНОВА, ТАТЬЯНА, БОГИ ЗЕМЛИ КАЗЫМСКОЙ, ТОМСК : ИЗДАТЕЛЬСТВО ТОМСКОГО УНИВЕРСИТЕТА

NIGLAS Liivo, 1997, “Reindeer in the Nenets Worldview”, Pro Ethnologia 5, p. 7-33.

NIGLAS Liivo, TOULOUZE Eva, 2004, “Yuri Vella's Worldview as a Tool for Survival: What Filming Reveals", Pro Ethnologia 17, p. 95-114.

NOVIKOVA 1998 = НОВИКОВА, Н.И., « КАК ЖИВЕТСЯ ОЛЕНЬЮ ПРЕЗИДЕНТА РОССИИ », ЖИВАЯ АРКТИКА, ИНФОРМАЦИОННЫЙ БЮЛЛЕТЕНЬ, N 1-2, С. 21-24.

NOVIKOVA 1999a = НОВИКОВА, Н.И., « ПРЕЗИДЕНТСКИЙ ОЛЕНЬ », ТРУД, 12. ФЕВРАЛЯ, 19. NOVIKOVA 1999b = НОВИКОВА, Н.И., « В ЧУМЕ ЖДУТ ОТВЕТА », НЕЗАВИСИМАЯ ГАЗЕТА 17.09.1999. NOVIKOVA 2000 = НОВИКОВА, Н.И., « ОТ ЧУМА НА ЦЕНТРАЛЬНОЙ ПЛОЩАДИ ДО СУДА » URL : http://jurivella.ru/vanaweb/index.php/2009-07-30-13-15-45/86-2009-08-20-16-43-50? format=pdf

NOVIKOVA 2002 = НОВИКОВА, Н.И., « КАК ЖИВЕТСЯ ОЛЕНЬЮ ПРЕЗИДЕНТА РОССИИ », in РАСЫ И НАРОДЫ, ВЫП. 28, ИНСТИТУТ ЭТНОЛОГИИ И АНТРОПОЛОГИИ ИМ. Н.Н. МИКЛУХО-МАКЛАЯ, МОСКВА : НАУКА, р. 133-146.

PROZES Jaak, 2013, „Inimene sünnib tõesti esivanemate hingest ! Juri Vella viimane intervjuu“, 10. märtsil 2013, Sirp 18.10.2013.

RADIN Paul 2008 [1956], “The Winnebago Trickster Figure”, in Michael LAMBEK(ed), A Reader in Anthropology of Religion, Blackwell Publishing, p. 226-237.

ROMBANDEEVA 1993 = РОМБАНДЕЕВА, Е.И., ИСТОРИЯ НАРОДА МАНСИ (ВОГУЛОВ) И ЕГО ДУХОВНАЯ КУЛЬТУРА (ПО ДАННЫМ ФОЛЬКЛОРА И ОБРЯДОВ), СУРГУТ : СЕВЕРНЫЙ ДОМ. 
SCHMIDT Éva, 1989, "Bear Cult and Mythology of the Northern Ob-Ugrians", in Mihály HOPPÁL (ed), Uralic Mythology and Folklore, Ethnologica uralica 1, Budapest: Ethnographic Institute of the Hungarian Academy of Sciences, p. 187-232.

SIIKALA Anna-Leena, 2000, "From Sacrificial Rituals into National Festivals: Post-Soviet Transformations of Udmurt Tradition", in Pertti J. Anttonen et al. (eds), Folklore, Heritage Politics and Ethnic Diversity. A Festschrift for Barbro Klein, Botkyrka, Sweden: Multicultural Centre, p. 57-85. TOULOUZE Eva, NIGLAS Liivo, 2012, "Native Spirituality in (Re)constructed Personhood: Observing and Filming Yuri Vella", Folklore. Electronic Journal of Folklore, 51, Tartu, p. 133-170.

UTROM 2003 = « ЕЛЬЦЫН, ПУТИН И ПРЕЗИДЕНТСКИЙ ОЛЕНЬ », Freitag, 03.10.2003.

WIGET Andrew, BalalaeVa Olga, 2011, Khanty, People of the Taiga: Surviving the 20th Century, Fairbanks: University of Alaska Press.

\section{NOTES}

1. Aasta varem oli Juri Vella korraldanud püstkojaga piketi Hantõ-Mansiiskis autonoomse ringkonna peahoone ees. Tollane naftatööstuse laiendamise-vastane pikett leidis piisavalt avalikku vastukaja (Novikova 2002). Seega oli loogiline, et naftafirmad ei soovinud uue piketi korraldamist.

2. Miljon rubla oli 1996. aasta aprillis väärt umbes 200 dollarit.

3. Kaltaš-imi - hantide peajumalanna, kes annab igale inimesele sündimisel hinged ja määrab samas ka eluea pikkuse. Kaltaš on handi peredes esimese tütre kaitsevaim. Ta on suurema osa jumalate ema või vanaema, määrates neile valitsemiseks territooriume ja andes neile spetsiifilisi ülesandeid. Tema ilmumiskuju on luik. Kaltaš-imi teised nimed on 'Tuhanded Naisjumalad Loonud Suur Naine, Tuhanded Meesjumalad Loonud Suur Naine‘,'Puutumatu Luik','[kõige vanem, kõige targem] Ema', 'Hõbedajuukseline Suur Naine‘. (Moldanov, Moldanova 2000: 37-50) 